\title{
Effect of Every-Other Furrow Irrigation on Water Use Efficiency, Starch and Protein Contents of Potato
}

\author{
Mohammad Shayannejad (Corresponding author) \\ Department of Irrigation, College of Agriculture \\ Shahrekord University, Shahrekord, Iran \\ Tel: 98-381-442-4532 E-mail:shayannejad@yahoo.com \\ Ali Moharrery \\ Department of Animal science, College of Agriculture \\ Shahrekord University, Shahrekord, Iran
}

\begin{abstract}
The every-other furrow irrigation is one of the mothods of deficit irrigation in furrow irrigation system. In this research, a randomized complete block design with three irrigation treatment and four replication on potato was stablished in Agricultural Research Center,Shahrekord, Iran. The irrigation treatments were: normal furrow irrigation(N), fixed every-other furrow irrigation(F) and alternative(variable) every-other furrow irrigation(V). The frequency of irrigation was constant and depth of it was calculated by measurement of soil moisture deficit and the volume of irrigation water was measured by a volumetric counter. The water and soil quality was normal (EC less than $1 \mathrm{ds} / \mathrm{m}$ ). The different fertilizers were used. After harvesting, water use efficiency, starch and protein content were measaured for each plot. There was significant difference between water use efficiency under different treatments, so that, the $\mathrm{F}$ treatment had the most water use efficiency. The every-other furrow irrigation decreased the starch content significantly. The $\mathrm{V}$ treatment increased the starch content significantly related to $\mathrm{F}$ treatment. There was no significant difference between the protein contents in the three treatments.
\end{abstract}

Keywords: Every-other furrow irrigation, Water use efficiency, Starch, Protein

\section{Introduction}

Potato is one of the most important and popular crops throught the word. The crop has attained great importance and popularity during the past two decades (Kashyap and Panada,2003). Potato needs frequent irrigation for its good growth and yield. The yield quality is greatly influenced by amount of applied water.(Marutani and Guz, 1989, Trebejo and Midmore,1990). Storage of water in arid and semi arid regions of iran is an important limiting factor in crop production. Deficit irrigation is one of the methods for this purpose, because it is able to increase benefit and water use efficiency. Plants with short growing season and good resistance to water stress are suitable for deficit irrigation. One of the best methods of deficit irrigation in furrow irrigation method, is every- other furrow irrigation. Each plant is irrigated by infiltration from one side of furrow in this method. This method promotes irrigation efficiency and prevents losses of water (Fischbach et al.,1974, Musick et al.,1982, Stone et al. 1993). For example, water use efficiency of sugarbeet was determined under every-other furrow irrigation in Shiraz, Iran, so that, this method increased the water use efficiency significantly (Sepaskhah et al.,1997). However, the result of New(1971) for sorghum and Samadi and Sepaskhah(1984) for dry bean indicated a significant yield reduction in every-other furrow irrigation. The reduction of yeild was due to the smaller amount of applied water and apparent imposed soil moisture stress, especially at the reproduction stage of grwth. Every0other furrow irrigation with supplemenary every-furrow irrigation at pod filling stage produced the highest bean daily with a smaller amount of water compared with the every-furrow irrigation(Samadi and Sepaskhah,1984). Crop yield may increase by using proper irrigation scheduling. Grain yeild of fingermillet was increased at more frequent irrigation intervals(Vanangamudi et al.,1990). Moorby et al.(1975) concluded that the everyother furrow irrigation method had no significant effect on the sugar and starch contents of potato. The objectives of 
this research were to determine water use efficiency, starch and protein contents of potato under every-other furrow irrigation and compare with every-furrow irrigation results.

\section{Materials and methods}

The experiment was conducted on potato (Marfona cultivar) at center of agricultural research of Shahrekord, Iran in 2004. Some soil properties prior to planting are shown in Table 1.

The design of the experiment was a randomized complete block with four replications and consisted of three treatments of furrow irrigations: (1): every-furrow irrigation or normal method $(\mathrm{N})$ in which water has been applied to every furrow ;(2): fixed every-other furrow irrigation (F) in which water has been applied as fixed every-other throughout the growth saeson ; and (3): variable or alternative every-other furrow irrigation (V) which is similar to $F$, but water has been applied to the furrow which was dry in the previous irrigation cycle. Therefore there was 12 plots in which there were 6 furrows with $10 \mathrm{~m}$ long and $0.75 \mathrm{~m}$ spacing. The irrigation interval was 7-day and amount of water for each irrigation was determined by measuring the soil water content in root zone by gypsum block before irrigation and raising the soil moisture to field capacity. The volume of irrigation water was measured by a volumetric counter and it is shown in Table 2. (Runoff was zero). According to this Table, the treatment were applied since $5^{\text {th }}$ irrigation. The water and soil quality was normal( EC less than $1 \mathrm{ds} / \mathrm{m}$ ).

Potato were planted to a distance of about $0.3 \mathrm{~m}$ in the rows and $0.1 \mathrm{~m}$ deep on May 25, 2004. Nitrogen, phosphorous, potasium and micro fertilizers were applied prior to planting and during growing season base on requirement. Potato yeilds were harvested on September 26 in the same year. The yeilds were weighted, water use efficiency was determined in each plot. The starch and protein contents were measured in each plot by AOAC(Association of Official analytical Chemists. by Williams,1984) and Kejeldal method respectively.

\section{Results}

The average water use efficiencies(WUE) were 621, 772 and 710 grams dry mass per cubic meter and 2.87, 3.51 and 3.23 kiligrams wet mas per cubic meter for N, F and V treatments respectively(Table 3 and 4). The WUE and its analysis of variance has been manually made and shown in Table 5 and 6 . According to Table 5 and 6 , there is significant difference(significance level is $5 \%$ ) between WUE (dry and wet) under three treatments. According to these Tables and based on mean comparison test (Duncan's test), there is no significant difference between WUE under the F and $\mathrm{V}$ treatments However, we can conclude that every-other furrow irrigation with normal water irrigation has a significant effect on WUE.

The average of starch contents were $66.66,62.09$ and $64.54 \%$ for N, F and V treatments respectively (Table 7) and its analysis of variance has been shown in Table 4. According to Tables 8 , there is significant difference(significance level is $1 \%$ ) between starch contents under the three treatments while every-other furrow irrigation method decreased the starch content significantly. According to Tables 8 and mean comparison tests, there is significant difference(significance level is $5 \%$ ) between starch contents under the $\mathrm{F}$ and $\mathrm{V}$ treatments, so that the starch content in the $\mathrm{V}$ treatment is more than $\mathrm{F}$ one.

The average of protein contents were $8.41,7.67$ and $8.97 \%$ for N, F and V treatments respectively (Table 9) and its analysis of variance has been shown in Table 6. According to Tables 10 there is no significant difference between protein contents under the three treatments.

\section{Discussion}

The every-other furrow irrigation is one of the methods of deficit irrigation in furrow irrigation. It was concluded that the every-other furrow irrigation method increased the WUE and decreased the starch content and was no effect on protein content of potato in the studied area. There was no significant difference between fixed and alternative every-other furrow irrigation methods except for starch content,so alternative method increased starch related to fixed method. Because the starch content of potato irrigated by every-other furrow irrigation method, is suitable for nutrition and this method save the application water, so this method is proposed for the studied area. This research showed that the every-other furrow irrigation method can be saved water and increased area under cultivation about $62 \%$ ( 45 divided to 27.9 from last row of Table 2) and increased yield about $22 \%$ (3.51 divided to 2.87 from last row of Table 3 ) and $12 \%$ (3.23 divided to 2.87 from last row of Table 3 ) in fixed and alternative methods respectively.

\section{Acknowledgments}

The authors appreciate Shahrekord University and center of agricultural research of Shahrekord, Iran because this research was supported by them.

\section{References}

Fischbach, P. E., and Mullinter, H. R. (1974). Every-other furrow irrigation of corn. Trans. ASAE, 17:426-428. 
Kashyap, P. S., and Panda, R. K. (2003). Effect of irrigation scheduling on potato crop parameters under water stressed condition. Agricultural Water Management, 59:49-66.

Marutani, M., and Guz, F. (1989). Influence of supplemental irrigation on development of potatoes in the tropic. Hort. Sci., 24(6), 920-923.

Moorby, J., Munns, R., and Walcott, J. (1975). Effect of water deficit on photosynthesis and tuber methabolism in potatoes. Australian Journal of Plant Physiology, 2(3): 323-333.

Musick, J. I., and Dusck, D. A. (1980). Planting data and water deficit effects on development and yield of irrigated winter wheat. Agronomy J.,72:45-52.

New, L. (1971). Influence of alternate furrow irrigation and time of application on grain sorghum production. Tex. Agric. Exp. Rep., No. 2953, pp.26-32.

Samadi, A. and Sepaskhah, A.R. (1984). Effects of alternate furrow irrigation on yield and water use efficiency of drt beans. Iran Agric. Res., 3:95-115.

Sepaskhah, A. R., and Kamgar-Haghighi, A. A. (1997). Water use and yield of sugerbeet grown under every-other furrow irrigation with different irrigation intervals. Agricultural Water Management, 34:71-79.

Stone, J. F. and Nofziger, D. L. (1993). Water use and yields of cotton grown under wide-spaced furrow irrigation. Agricultural Water Management, 24:27-38.

Trebejo, I., and Midmore, D. J. (1990). Effect of water stress on potato growth. J. Agric. Sci., 114, 321-330.

Vanangamudi, K., Selvaroj, K.V. and Kulandaivelu, R. (1990). Influence of irrigation on the yield quality of fingermillet. Seed Sci. Technol., 18:283-286.

Table 1. Soil properties prior to planting

\begin{tabular}{cccccccc}
\hline $\mathrm{Ca}+\mathrm{Mg}$ & $\mathrm{P}$ & $\mathrm{N}$ & $\mathrm{K}$ & $\mathrm{Na}$ & $\mathrm{PH}$ & $\mathrm{EC}$ & Texture \\
$(\mathrm{meq} / \mathrm{l})$ & $(\mathrm{mg} / \mathrm{kg}$ & $(\%)$ & $(\mathrm{mg} / \mathrm{kg}$ & $(\mathrm{mg} / \mathrm{kg}$ & & $(\mathrm{ds} / \mathrm{m})$ & \\
& soil $)$ & & soil $)$ & soil $)$ & & & \\
\hline 1.7 & 36.96 & 0.066 & 6.9 & 6.1 & 6.49 & 0.19 & Silty clay \\
\hline
\end{tabular}


Table 2. Irrigation scheduling

\begin{tabular}{|c|c|c|c|c|}
\hline Irrigation No. (1) & VF (2) & VPN (3) & VPE (4) & VT (5) \\
\hline 1 & 0.55 & 3.3 & 3.3 & 39.6 \\
\hline 2 & 0.36 & 2.16 & 2.16 & 25.92 \\
\hline 3 & 0.41 & 2.46 & 2.46 & 29.52 \\
\hline 4 & 0.48 & 2.88 & 2.88 & 34.56 \\
\hline 5 & 0.56 & 3.36 & 1.68 & 26.88 \\
\hline 6 & 0.6 & 3.6 & 1.8 & 28.8 \\
\hline 7 & 0.58 & 3.48 & 1.74 & 27.84 \\
\hline 8 & 0.53 & 3.18 & 1.59 & 25.44 \\
\hline 9 & 0.51 & 3.06 & 1.53 & 24.48 \\
\hline 10 & 0.49 & 2.94 & 1.47 & 23.52 \\
\hline 11 & 0.48 & 2.88 & 1.44 & 23.04 \\
\hline 12 & 0.44 & 2.64 & 1.32 & 21.12 \\
\hline 13 & 0.4 & 2.4 & 1.2 & 19.2 \\
\hline 14 & 0.39 & 2.34 & 1.17 & 18.72 \\
\hline 15 & 0.38 & 2.28 & 1.14 & 18.24 \\
\hline 16 & 0.34 & 2.04 & 1.02 & 16.32 \\
\hline Sum & - & 45 & 27.9 & 403.2 \\
\hline
\end{tabular}

(2):Volume of water entried to one furrow(cubic meter)

(3): Volume of water entried to one plot with fixed or alternative every other furrow(cubic meter)

(4):Volume of water entried to one plot with normal furrow(cubic meter)

(5):Volume of water entried to total farm(cubic meter $)=(4) * 8+(3) * 4$

Table 3. The results of WUE (based on wet mass, $\mathrm{Kg} / \mathrm{m}^{\wedge} 3$ )

\begin{tabular}{cccc}
\hline $\begin{array}{c}\text { Treatment } \\
\text { Replication }\end{array}$ & $\mathrm{N}$ & $\mathrm{F}$ & $\mathrm{V}$ \\
\hline 1 & 2.47 & 3.21 & \\
\hline 2 & 2.98 & 3.26 & 3.19 \\
\hline 3 & 2.91 & 3.73 & 3.15 \\
\hline 4 & 3.13 & 3.84 & 3.48 \\
\hline average & 2.87 & 3.51 & 3.23 \\
\hline
\end{tabular}


Table 4. The results of WUE (based on dry mass, $\mathrm{Kg} / \mathrm{m}^{\wedge} 3$ )

\begin{tabular}{cccc}
\hline $\begin{array}{c}\text { Treatment } \\
\text { Replication }\end{array}$ & $\mathrm{N}$ & $\mathrm{F}$ & $\mathrm{V}$ \\
\hline 1 & 499 & 717 & 722 \\
\hline 2 & 599 & 698 & 654 \\
\hline 3 & 629 & 758 & 691 \\
\hline 4 & 758 & 917 & 774 \\
\hline average & 621 & 772 & 710 \\
\hline
\end{tabular}

Table 5. Analysis of variance for WUE (based on wet mass)

\begin{tabular}{ccccc}
\hline SV & DF & SS & MS & Fs \\
\hline Block & 3 & 0.45 & 0.15 & 4.9 \\
\hline Treatment & 2 & 0.81 & 0.41 & \\
\hline Error & 6 & 0.19 & 0.03 \\
\hline Total & 11 & 1.45 &
\end{tabular}

Table 6. Analysis of variance for WUE (based on dry mass)

\begin{tabular}{ccccc}
\hline SV & DF & SS & MS & Fs \\
\hline Block & 3 & 56910 & 18970 & 7.71 \\
\hline Treatment & 2 & 46225 & 23112 & 9.4 \\
\hline Error & 6 & 14757 & 2460 & \\
\hline Total & 11 & 117892 & \\
\hline
\end{tabular}

Table 7 . The results of starch content $(\%)$

$\begin{array}{llll}\text { Treatment } & \mathrm{N} & \mathrm{F} & \mathrm{V}\end{array}$

Replication

\begin{tabular}{cccc}
\hline 1 & 64.87 & 61.91 & 64.54 \\
\hline 2 & 68.74 & 64.3 & 66.05 \\
\hline 3 & 67.26 & 60.37 & 64.64 \\
\hline 4 & 65.76 & 61.76 & 62.93 \\
\hline average & 66.66 & 62.09 & 64.54 \\
\hline
\end{tabular}


Table 8. Analysis of variance for starch content

\begin{tabular}{ccccc}
\hline SV & DF & SS & MS & Fs \\
\hline Block & 3 & 15.52 & 5.17 & 5.16 \\
\hline Treatment & 2 & 41.9 & 20.95 & \\
\hline Error & 6 & 6.01 & 1 & \\
\hline Total & 11 & 63.43 & & \\
\hline
\end{tabular}

Table 9. The results of protein content $(\%)$

\begin{tabular}{cccc}
\hline $\begin{array}{c}\text { Treatment } \\
\text { Replication }\end{array}$ & $\mathrm{N}$ & $\mathrm{F}$ & $\mathrm{V}$ \\
\hline 1 & & & \\
\hline 2 & 8.81 & 4.39 & 9.14 \\
\hline 3 & 7.48 & 9.23 & 8.95 \\
\hline 4 & 7.97 & 8.36 & 8.97 \\
\hline average & 9.38 & 8.69 & 8.82 \\
\hline
\end{tabular}

Table 10. Analysis of variance for protein content

\begin{tabular}{ccccc}
\hline SV & DF & SS & MS & Fs \\
\hline Block & 3 & 3.72 & 1.24 & 0.56 \\
\hline Treatment & 2 & 3.41 & 1.71 & 0.78 \\
\hline Error & 6 & 13.2 & 2.2 & \\
\hline Total & 11 & 20.3 & \\
\hline
\end{tabular}

